converge into an unvisited lake west or south-west of this." If the expression "one water" here means that these two lakes are united by an extension of one into the other, and not by a river, then it is evident that the river and lake chain under consideration can never flow up to join either of them after having passed down through the rent in the Mountains of Rua; if it means that these lakes are joined together by a river, still the small difference in height between that computed for Lake Tanganyika by Mr. Finlay, of 2,800 feet (afterwards so curiously confirmed by Livingstone's height of Lake Liemba), and that found for the Albert Nyanza by Baker, would not give a sufficient lowness to the latter lake to allow this river to flow down to it through the five degrees of latitude which separate its outfall from the Mountains of Rua, from the southern end of the Albert Lake. Dr. Livingstone's statement in his letter above quoted from Ujiji, that the head waters of the Tanganyika and Albert Lakes are 300 miles south of that place, is not at all opposed to the view that the Chambeze River and its lake chain may join the Congo, for the streams which flow into his Lake Liemba may rise at this distance from Ujiji. In this case the sources of the Nile would be side by side with those of the Congo; and the man who has the claim to be called the greatest explorer that the world has ever known, has the double honour of having solved the two greatest of African problems.

74, Strand, W.C. KEITH Johnston, Jun.

\section{Physical Meteorology}

AsSUMING with your correspondent that there is an ascending current in the heart of a cyclone, no doubt latent heat will play its part. I presume, however, your correspondent does not imagine that air is ever actually heated by such means to $370^{\circ} \mathrm{F}$.

Suppose, for instance, that two cubic feet of saturated air, both at thirty inches pressure, but one at the temperature $32^{\circ} \mathrm{F}$. and the other at the temperature $90^{\circ} \mathrm{F}$, become mixed. The cubic foot at $32^{\circ} \mathrm{F}$. will contain 2.37 grains of vapour, that at $90^{\circ} \mathrm{F}$. 14.50 grains. Hence, after mixture the average weight of vapour in unit of volume will be 8.43 grains. This would saturate a temperature $=717^{\circ} \mathrm{F}$. But this is greater than the mean between the two temperatures or $6 I^{\circ} \mathrm{F}$. There will, therefore, be hardly enough heat to keep the mixture at $71^{\circ} \cdot 7 \mathrm{~F}$. and prevent deposition.

On the other hand, we cannot imagine the temperature of the mixture to fall as low as $6 \mathrm{I}^{\circ} \mathrm{F}$.

The temperature of the mixture will therefore, I presume, be greater than $61^{\circ}$ and less than $71^{\circ} 7^{\circ}$.

\section{B. StEWart}

\section{Veined Structure in Ice}

FEW men have had better opportunities of examining glacial phenomena than Mr. Whymper, and his explanation of the veined structure is certainly an ingenious one. I venture, however, to doubt whether it can be regarded as generally satisfactory, although, possibly, it might explain some isolated cases.

The following, which, so far as my experience goes, are common facts in glaciers, appear to me difficult to reconcile with his explanation.

(I.) One common case in which the veined structure becomes conspicuous is after the glacier has been pressed into a narrower channel than has been occupied by its névé. The structure planes are then roughly parallel to the sides of the channel. Dr. Tyndall has pointed this out in his "Glaciers of the Alps," $p$. 387 , and $\mathrm{I}$ have frequently observed the same thing myself. Three instances occur to me at this moment: one on the Cxorner Glacier, under the Gorner Grat; another in the middle part of the Glacier de la Pilatte (Dauphine); a third on the upper part of the Mer de Glace. Did I search through my note-book I have no doubt I could find plenty more. If now, say in the second example, the veined structure was due to the crevasses in the ice fall below the Col du Sélé, sturely its planes would hardly be twisted through a right angle in the comparatively short distance intervening between the ice fall and the rocky spur from the Crête des Boeufs Rouges which causes the "nip." Moreover, if the planes have been turned by the unequal motion of the centre and sides of the ice stream, ought we to find them so uniform in direction as they now are, often extending with a very general parallelism over the greater part of the glacier?

(2.) If the veined structure is the result of healed crevasses, how are we to explain the great number of these plates of different coloured ice on glaciers which are not remarkable for very nume- rous crevasses. For example, on the Roseg Glacier, near Pontresina, these plates of blue and white ice alternate with each other for at least several hundred yards as you walk up the glacier, and are commonly only an inch or so thick. I have in my notebook a diagram of a piece to exhibit the weathering of the two kinds of ice, in which are shown five plates, three blue and two white. One of the former is about an inch thick, and all the rest are thimner. Each of the white is about half an inch, and I remember that this was a fair sample of most of the ice near. If, then, the crevasses, from whose healing this platy structure has resulted, were formed simultaneously or in close succession, how are we to explain the thinness of the. white portion, its layers being, if anything, thinner than the blue? Crevasses are not usually so near together as this, and if they were not thus formed is it probable that the plates would be so produced as to be, for about as far as one could trace them, parallel one to another, so accurately that my diagram looks like a bit from a cliff of midland lias?

Cambridge, Jan. 7

T. G. BONNEY

\section{Personal Equation of Astronomical Observers}

IN the number for November 18, I 869, of NATURE, " J." asks if an experiment has hitherto been tried to ascertain the value of the personal equation of astronomical observers. The fact is, that it has been tried in different manners, as by Mr. Wolf in Paris, and Mr. Hirsch in Neuchatel, but first of all by Dr. F. Kaiser, Astronomical Professor, and Director of the Observatory of Leiden. The apparatus of Prof. Kaiser was first constructed in $185 \mathrm{I}$, but was afterwards highly improved, so that it is fitted equally well for observations with or without the chronograph.

A description of the method and apparatus of M. Kaiser is to be found in the "Archives Néerlandaises des Sciences exactes et Naturelles,"vol. i. p. 194, and of the improved one in the reports and communications of the Royal Academy of Science of the Netherlands (Verslagen en mededeelingen der Konink]ijke Academie van Wetenschappen), Second Series, vol ii. the former is written in French, and titled: "Sur la détermination absolue de l'erreur personelle dans les observations astronomiques ;" the latter, in German : "Uebereinen neuen Apparat zur absoluten Bestimmung von persönlichen Fehlern bei astronomischen Beobachtungen." H. VON DE STADT, Ph.D. Arnheim, Netherlands, January 3

\section{Anatomical Lectures to Female Medical Students}

I HAVE great pleasure in hearing that the Professors of Anatomy in Scotland have not all forgotten that women ought to be treated with some degree of chivalry.

Professor Struthers, of Aberdeen, and Professor Bell, of St. Andrews, hearing that the five ladies who are studying at the Edinburgh University are excluded from the opportunity of studying anatomy there, have severally offered their services as instructors. Many a lady will rejoice that the numbers of those willing and ready to help in the good cause of fuller knowledge for women are increased by two professors, who have bravely come forward with much moral courage and chivalrous feeling. Edinburgh, Jan. 22. a Non-medical Woman

\section{NOTES}

THE Physical Section of the Academy of Sciences at their last meeting recommended Professor Kirchhoff, of Heidelberg, to fill the place of correspondent of the section, vacant by the death of Principal Forbes. The other candidates were MM. Angström, Billet, Dove, Grove, Henry (of Philadelphia), Jacobi, Joule, Lloyd (of Dublin ), Riess, Stokes, Tyndall, Volpicelli, and Sir William Thomson.

IN our statement last week that "the Senate of London University has proposed to establish a Faculty of Science," "London University" should have been "University College, London;" the fact being that the Senate of the University of London-in advance of every other university of the kingdom-established a Faculty of Science ten years ago; constituting, at the suggestion, and with the advantage of the advice, of the ablest men of science in this country, a scheme for graduation in science, which has continued in efficient operation from that time to the present. And we may add that in the new building of the University the 